\title{
nature
}

Vol 436 | Issue no. 7054 | 25 August 2005

\section{Greens can be good for you}

\author{
Next month's general election in Germany may see the end of the Green Party's spell in government. The \\ party has fared well, as has science with it, except where ideology won out over good sense.
}

$\uparrow$

he Green movement in Germany was born almost 30 years ago when a loose coalition of pacifists, antinuclear campaigners and socialist intellectuals united to form an extraparliamentary movement of discontent and nonconformism. The surge quickly gained momentum and became a political party that sought to pursue the cause of the environment and little else.

With hindsight, the party's romantic attachment to the ideals espoused by philosopher Jean-Jacques Rousseau in the eighteenth century was absurdly anachronistic, opposing almost everything that doesn't grow on trees - from artificial fertilizers to plastic bags and computers. No wonder that the establishment, and many scientists, were deeply suspicious of the emerging new force.

Over the years, the Greens have jettisoned their excess antimodernism. Nevertheless, when the reformed party came to power in 1998 as the Social Democrat's coalition partner, scientists in Germany were nervous about where it might lead. Now, with an upcoming election in which the Greens are unlikely to retain power, it is an appropriate moment to take stock of their achievements.

\section{Welcome progress}

By and large, and with some notable exceptions, the Greens have helped sustain and develop Germany's science base. Public science budgets have increased during the past seven years, which they hadn't under the previous government. In areas where the Green's core interests reside, research opportunities have flourished. Encompassing such essential disciplines as alternative and renewable energies, clean environment technologies, biodiversity, coastal protection and marine sciences, this is welcome progress.

Despite early fears, the Greens have not fuelled controversy over the use of animals in research, nor have they been responsible for Germany's overly restrictive regulation of stem-cell research. Indeed, the loudest opposition to some aspects of modern biomedicine comes from the conservative Christian Democrats, who look likely to win the election if their leader Angela Merkel can quickly improve on her shaky initial campaign.

The Green ministers for agriculture and the environment, Renate Künast and Jürgen Trittin, respectively, have gained Europe-wide respect for their political handling of two key issues: Künast for her rigorous crisis management of the BSE (mad cow disease) calamity, and Trittin for enticing German industry into an agreement on greenhouse-gas emissions trading. Green power and science have also prospered alongside each other at a municipal level. Witness Konstanz and Freiburg, for example - cities in southwest Germany which both host large research universities and, thanks to the large student electorate, are governed by Green mayors. But it is mostly thanks to Joschka Fischer, the popular Green minister of foreign affairs, that the former single-issue party is now respected for its broad competence in societal issues.
Blame where it's due, however: Green politicians, and their voters, still display deep-rooted reservations when it comes to technological advance as a means of solving problems. This is where Green principles have clashed with those of the Social Democrat science minister, Edelgard Bulmahn.

Tensions escalated in March this year over a grant application to the research ministry for risk research on transgenic plants. The application came from the Federal Biological Research Centre for Agriculture and Forestry, which is subordinate to Bulmahn's ministry. Künast insisted that the application should be withdrawn. The reasons were never clear, and Künast has not shaken off the suspicion that she blocked research to which she was hostile.

Hostilities have been most manifest in the Green's approach to nuclear energy. Phasing out nuclear energy by 2020 was a cornerstone of the Social-two parties' coalition agreement. But while it was in accord with the public mood, it also inevitably led to an unprecedented loss of
"Greens still display deeprooted reservations when it comes to technological advance as a means of solving problems." scientific competence in fission-reactor technology and safety research, and was an outrageous waste of capital. Unsurprisingly, nuclear-physics departments at German universities are already finding it difficult to attract students and $\mathrm{PhD}$ candidates.

\section{Missed opportunities}

It is also thanks to the Greens that Germany will contribute less than it should to the construction of the international fusion reactor ITER in Caderache, France. Sceptical Green members of the parliamentary research committee have destroyed a substantial opportunity for German scientists and engineers.

The same applies to plant biotechnology. Although Germany is well positioned in plant genetics, the restrictive regulatory framework set up by Künast makes it difficult to reap the benefits of basic research. Recently proposed liability rules are far stricter than anywhere else in the European Union and will deter investors. If the law passes, Germany could suffer the same fate in its crop trade as it did in the past with genetically engineered drugs. For example, despite its strong pharmaceutical industry, Germany has to import insulin.

No one should expect the Greens to abandon their principles, but one can expect them to be more prepared to end short-sighted hostilities in the longer-term interests of the sustainable environment and society about which they care so much.

The German experiment has shown that, such myopias aside, the Green party has been more open-minded, versatile and science friendly than most had believed it capable of. A right-liberal government (or a grand coalition) has yet to prove that it can do better for science and for society's resources. 